\title{
Transport Characteristics of Selected Dyes Through Track-Etched Multiporous Pet Membranes
}

\author{
Seçilmiş Boyar Maddelerin İz Aşındırılmış Çoklu Gözenekli \\ Pet Membanlardan Taşınım Özellikleri
}

\author{
Research Article \\ Dila Kaya and Kaan Keçeci* \\ İstanbul Medeniyet University, Department of Chemistry, Üsküdar, İstanbul, Turkey.
}

\section{ABSTRACT}

\begin{abstract}
We have investigated the transport properties of track-etched poly(ethylene terephthalate) (PET) $\checkmark$ membranes in order to pursue possible applications for effective separation and sensing purposes. We have obtained cylindrical and conical nanopores on PET membranes using symmetrical and asymmetrical track-etch methods, respectively. We have used the fabricated nanopores for the transport of charged dye molecules. Effect of applied potential, temperature and pore geometry was shown for crystal violet dye. We have also investigated the transport of methyl orange and shown negatively charged carboxylate groups on the PET nanopore walls along with applied potential enhanced the selective transport of cations. The temperature and the conical geometry were also found to promote the transport of cations.
\end{abstract}

\section{Key Words}

track-etched nanopore; mass transport; PET membrane; crystal violet; methyl orange.

\section{öz}

\begin{abstract}
- tkin ayırma ve algılama sağlayabilecek uygulamaların elde edilebilmesi amacıyla iz-aşındırılmış pol - (etilen tereftalat) (PET) membranlardan taşınım özellikleri araştırılmıştır. Simetrik ve asimetrik iz aşındırma yöntemleri ile PET membranlarda silindirik ve konik nanogözenekler oluşturulmuştur. Elde edilen nanogözenekler yükı̈̈ boyar maddelerin taşınımı amacıyla kullanılmıştır. Kristal Viyole boyar maddesi için potansiyel, sıcaklık ve gözenek geometrisinin taşınıma etkileri incelenmiştir. Metil Oranj boyar maddesinin taşınımı da ayrıca incelenmiş ve PET nanogözeneklerinin duvarında bulunan negatif yüklü karboksil grupları ve uygulanan potansiyelin katyonların seçici taşınımını arttırdığı gösterilmiştir. Sıcaklık ve konik geometrinin de katyonların taşınımını arttırdığı bulunmuştur.
\end{abstract}

\section{Anahtar Kelimeler}

iz-aşındırılmış nanogözenek; kütle taşınımı; PET membran; kristal viyole, metil oranj.

Article History: Received: Oct 20, 2017; Revised: Dec 06, 2017; Accepted: Dec 06, 2017; Available Online: Feb 20, 2018.

Dol: $10.15671 /$ HJBC.2018.209

Correspondence to: K. Keçeci; Istanbul Medeniyet University, Department of Chemistry, Uskudar, Istanbul, Turkey. 


\section{INTRODUCTION}

- anoporous (or nanochannelle) structures formed in solid materials are used in various separation techniques and sensing applications for biomolecules [1-3]. These structures/materials, can be biological or synthetic, and can be prepared to including single or multiple nanopores [4]. While single nanoporous materials are used for determination and detection at molecular level, studies based on selective transport of analytes from multiple nanopore membranes can also be performed.

Biological nanoporous structures are usually obtained with ion channels isolated from bacteria (eg, $\alpha$-hemolysin, maltoporin) inserted into lipid bilayer $[5,6]$. Biological nanopores are not resistant to factors such as $\mathrm{pH}$, temperature, ion concentration and potential, which entails the production of these structures synthetically [7]. The desired attributes for nanopores are that they are low cost, reproducible, chemically and thermally robust and stable. For this reason, synthetic nanoporous materials have been developed in order to overcome the disadvantages of biological nanopores. Some of the methods used to obtain these materials are nanopipettes [8], electron beam lithography [9,10], laser melting [11], and ion beam shaping [12,13]. In addition to these techniques, track-etching method, which is an easy method yielding reproducible sized pores with desired geometries, is often preferred [14-17]. Application areas of synthetic nanopores that can be obtained as a result of the development of synthetic methods include biomolecule characterization [18,19], desalination [20], determination of DNA sequences $[19,21]$ and molecular separation [22].

Transport from multiporous membranes has also high potential for biomedical applications [23]. Nanoporous membranes produced with desired pore size, density and thickness are alternatives for controlled release of pharmacological agents [24]. However, in order to use a membrane in such technologies, the selectivity or molecular flux of the nanoporous structure must be able to match the application in demand. It is also desired that the process of obtaining nanoporous membranes is economical and reproducible. For all these reasons, extensive research is needed on analyte transport from nanoporous membranes.
One of the most frequently used nanoporous materials is anodic aluminum oxide (AAO) membranes $[25,26]$. The geometry of the nanopores can be controlled by changing the conditions of the anodization process. However, the thickness of AAO membranes leads to very low molecular flow and transport rate making them unsuitable for most processes. Cylindrical nanopores can also be obtained by controlling various advanced technologies such as the use of focused ion beams in silicon ( $\mathrm{Si}$ ) and silicon nitride (SiN) membranes [27]. Although these membranes are thermally and chemically stable, the process of forming nanopores is quite expensive. Similarly, nanopores created on graphene are often used for purposes such as DNA analysis [19]. The greatest advantage of these membranes is their high durability, despite being very thin [28]. However, preparation of films from these expensive materials and subsequent processing of pores in these films are not economically feasible because special equipment is required. Therefore, in order to obtain nanoporous membranes, techniques such as tracketching which is both economically viable and enable effective separation and transport, can be preferred.

Charles Martin and his co-workers have published a series of papers on molecular transport using gold nanotubules obtained from tracketched polymer (polycarbonate-PC) membranes [29-33]. In order to control the surface properties and enable easier functionalization, they have performed electroless gold deposition onto the pore walls and modified the surface with functional groups using thiol chemistry. These functionalized gold nanotubules made it possible to enhance the selectivity and permeability of the membranes for certain analytes depending on their charge and size. Some examples on surface functionalization of polymer nanochannels for enhanced transport rates and selectivity include changing the surface charge by adding L-cysteine on the surface and therefore making it ion-permselective [29]; functionalizing with various groups such as polymers, organic acids etc. for discriminating different molecules [34] and functionalizing the pore surface of polyimide (PI) membrane with ethylenediamine, making it selective towards anions [35]. 


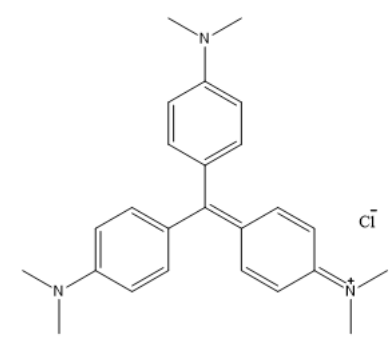

A

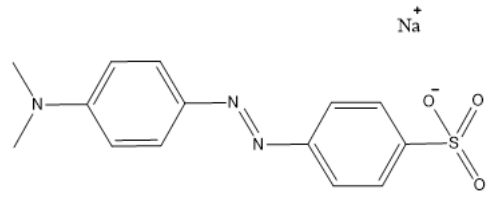

B

Figure 1. A: Crystal Violet (Triarylmethane dye, M: $407.99 \mathrm{~g} / \mathrm{mol}$ ); B: Methyl Orange (Azo dye, M: $327.33 \mathrm{~g} / \mathrm{mol}$ ).

Studies on analyte transport from multiporous polymers can either focus on surface functionalization of the nanopore in order to enhance the transport rate of the analyte or taking advantage of the already negatively charged wall of PET membrane which possess negative carboxyl (-COO) groups at neutral $\mathrm{pH}$ due to track-etching process [36].

In this work, we have prepared cylindirical and conical nanopores on PET membranes using track-etch method and investigated the transport characteristics of charged analytes through these membranes. The primary reasons for choosing PET membrane for the mass transport experiments were that it is easily track-etched (without the need of high temperatures or additional chemicals), mechanically robust, stable in extreme conditions of $\mathrm{pH}$ and temperature with a slightly negative surface charge density. The effects of applied potential, pore geometry and temperature were studied and the use of track-etched membanes for selective and effective transport of the analytes were shown.

\section{MATERIALS and METHODS}

\section{Experimental}

Poly(ethylene terephthalate) (PET) membranes (3 $\mathrm{cm}$ diameter, $12 \mu \mathrm{m}$ thickness) were obtained from Gesellshaft für Schwerionenforschung (GSI, Darmstadt-Germany). The membranes were irradiated with heavy ions (i.e., Au ion, $11.4 \mathrm{MeV}$ ) at various ion densities even down to 1 ion/membrane.

This was succeeded by defocusing the ion beam and using a metal mask with a $0.1 \mathrm{~mm}$ diameter aperture with a shutter system which shuts down the ion beam as the single ion passage was detected. All the membranes were exposed to UV irradiation ( $254 \mathrm{~nm}$ ) to saturate the damages in tracks. All solutions were prepared from deionized water (Millipore Direct-Q 5, Millipore Co.). Formic acid $(\mathrm{HCOOH})$, sodium hydroxide $(\mathrm{NaOH})$, crystal violet $\left(\mathrm{C}_{25} \mathrm{H}_{30} \mathrm{CIN}_{3}\right)$ (Figure $\left.1 \mathrm{~A}\right)$, methyl orange $\left(\mathrm{C}_{14} \mathrm{H}_{14} \mathrm{~N}_{3} \mathrm{NaO}_{3} \mathrm{~S}\right)$ (Figure 1B) and potassium chloride $(\mathrm{KCl})$ were purchased from Sigma Aldrich. All the chemicals were used as received without further purification.

\section{Fabrication of Nanopores}

PET membranes were treated with long-wave UV irradiation overnight in order to sensitize the tracks, increase the track etching rate and make the pores more homogeneous in size. Cylindrical nanopores were obtained on PET membranes using track- etch method. With this purpose, batch etching was performed in which the track membranes were suspended in a beaker filled with etching solution $(9 \mathrm{M} \mathrm{NaOH})$ for a predetermined time at room temperature. Afterwards, the membrane was kept in a beaker filled with stopping solution ( $1 \mathrm{M} \mathrm{HCOOH})$ for 30 minutes and finally the membrane was washed with di-water to remove possible residues from the membrane surface.

Conically shaped nanopores were obtained using a previously discussed asymmetric chemical etching technique [37]. Shortly, the membrane was mounted between the two halves of a conductivity cell with UV-treated side of the membrane facing the alkaline etching solution ( $9 \mathrm{M} \mathrm{NaOH}$ ) and the other side facing the stopping solution $(1 \mathrm{M} \mathrm{HCOOH}$ and $1 \mathrm{M} \mathrm{KCl}$ ). Platinium (Pt) electrodes were immersed into each cell and $1 \mathrm{~V}$ transmembrane potential was applied to monitor the breakthrough moment (Keithley 6487 picoammeter/voltage source, Cleveland, $\mathrm{OH}$, USA). After the etching process, etching solution was replaced with stopping solution for neutralization. Then, both cells were 


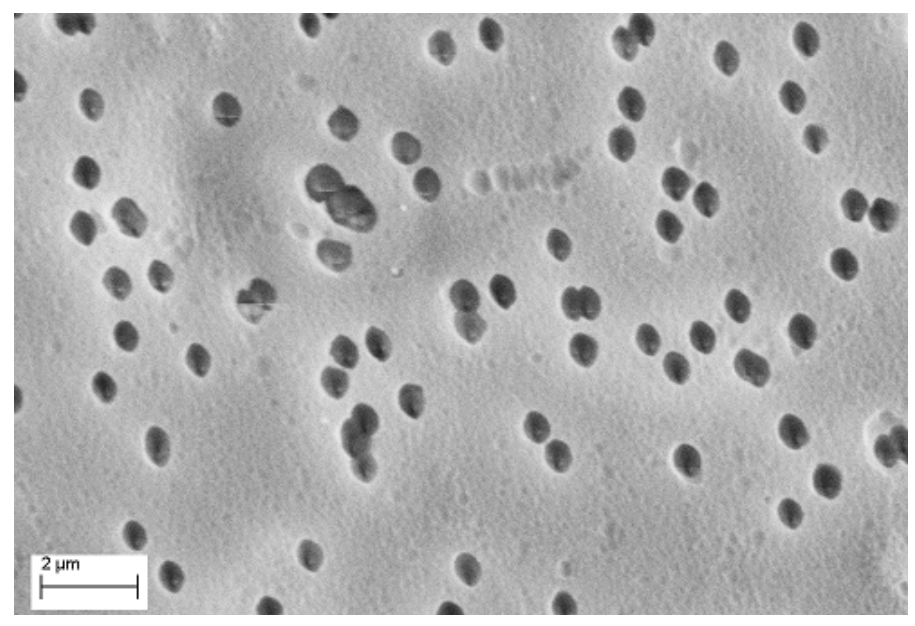

Figure 2. SEM image of multiporous PET etched for 2 hours.

rinsed with di-water to remove possible residues from the membrane surface. In the end, conically shaped nanopore was obtained with two different sized openings called base (large opening) and tip (small opening). The large opening of the nanopore $\left(\mathrm{d}_{\text {base }}\right)$ was directly determined from SEM images of multipore membranes while electrochemical measurements were performed for the calculation of small opening $\left(d_{t i p}\right)$ of the conical membrane. With this purpose, both halves of the conductivity cell were filled with electrolyte solution (i.e., $1 \mathrm{M} \mathrm{KCl}, 10 \mathrm{mM}$ PBS buffer at $\mathrm{pH}=7$ ) while the single nanopore membrane was mounted between these cells. $\mathrm{Ag} / \mathrm{AgCl}$ electrodes were used and potential was stepped between -1 $\mathrm{V}$ and $+1 \mathrm{~V}$. The resistance of the nanopore $(R)$ is proportional to the conductivity of solution $(\rho)$ the length of nanopore (I, thickness of the membrane), $d_{\text {base }}$ and $d_{\text {tip }}$ as given in Equation 1. R value was the reciprocal of the slope of I-V curve obtained from the electrochemical measurement and the tip diameter was calculated using Equation 1 (Conductivity measurements were carried out with a Mettler Toledo FE 30 conductivity meter).

$$
R=\frac{4 \rho l}{\pi d_{\text {tip }} d_{\text {base }}}
$$

\section{Mass Transfer Experiments}

The membranes were mounted between the two halves of an $\mathrm{H}$-cell to investigate the transport properties of charged analytes. The cell volumes were $5 \mathrm{~mL}$ with an effective permeation area of $0.3 \mathrm{~cm}^{2}$. The feed half-cell was filled with the known concentration of the analyte in phosphate buffer $(10 \mathrm{mM}, \mathrm{pH}=7)$ and the permeate half-cell contained only pure buffer solution. Phosphate buffer at $\mathrm{pH} 7$ was selected because at neutral $\mathrm{pH}$, nanopore surface charge of PET membrane is negative because of $-\mathrm{COO}^{-}$groups on its pore walls [38], crystal violet is positively charged and methyl orange is negatively charged $\left(\mathrm{pK}_{\mathrm{a}, \mathrm{MO}}=3.47 ; \mathrm{pK}_{\mathrm{a}, \mathrm{cv}}=9.4\right)$. Both halves of the cell were continuously stirred with a magnetic stirrer ( 1050 rpm). Samples were collected from the permeate cell at regular time intervals and the concentration of the analyte was determined using a UV-Vis spectrophotometer (Shimadzu-2600). A linear calibration curve of analytes of known concentrations was used for the spectrophotometric calculations.

\section{RESULTS and DISCUSSION}

Pore diameters of cylindrical pores and base diameters of the conical nanopores were obtained from the SEM images of multipore membranes $\left(10^{9}\right.$ nanopores $\left./ \mathrm{cm}^{2}\right)$. SEM image of a multipore PET membrane etched for 2 hours is given in Figure 2 with a calculated base diameter value of $533 \pm 47 \mathrm{~nm}$. An average of 20 pores were used to calculate the diameters with Image-J software and standard deviation values were taken into account.

A linear relationship was observed between etching time and pore diameter (Figure 3). The bulk etching rate, which equals the slope of the obtained linear plot, was found as $4.5 \pm 0.2 \mathrm{~nm}$. $\mathrm{min}^{-1}$. This linear relationship enabled reproducible production of nanopores with desired diameters. 


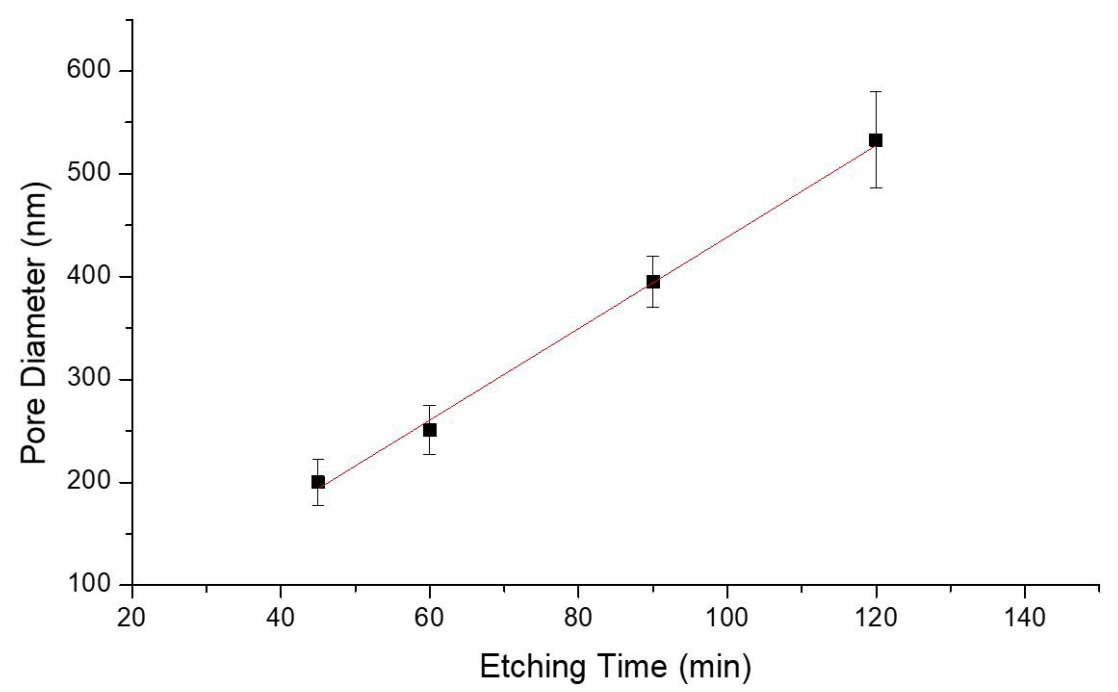

Figure 3. Pore diameter as a function of etching time.

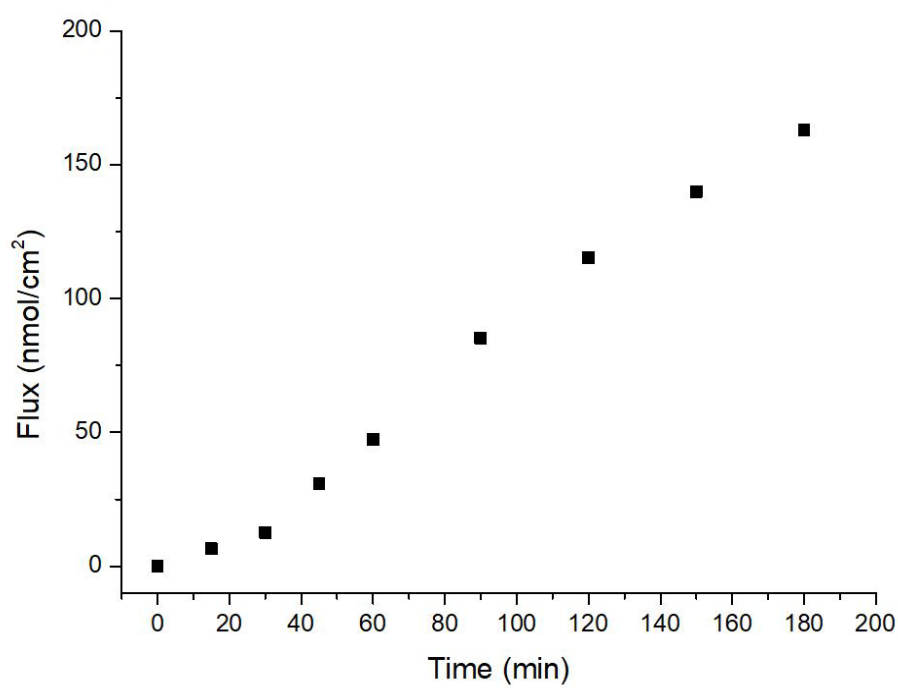

Figure 4. Permeation of $\mathrm{CV}^{+}$through $25 \pm 1 \mathrm{~nm}$ nanopores (Pore density: $10^{9}$ pore $/ \mathrm{cm}^{2}$ ).

\section{Permeation of the Analytes}

Permeation of $\mathrm{CV}^{+}$through the nanoporous membrane was conducted using a multiporous $\left(10^{9}\right.$ pore. $\left.\mathrm{cm}^{-2}\right)$ PET membrane with a pore diameter of $25 \pm 1 \mathrm{~nm}$. The transport of the positively charged dye was continued for three hours and the transported amount of the analyte $\left(\right.$ per $\mathrm{cm}^{2}$ ) increased linearly. Figure 4 shows the linear relationship of molecular flux and time with an $\mathrm{R}^{2}$ value of 0.990 . The permeation rate was calculated from the slope of the obtained line, which yielded the amount of analyte transferred per unit time.

\section{Effect of Potential on Analyte Transport Rate}

In order to investigate the potential dependency of molecular transport, an electric field was applied. Anode was immersed in the feed cell and cathode was immersed in the permeate cell in order to promote the transport rate of $\mathrm{CV}^{+}$. The flux data for the transport of $\mathrm{CV}^{+}$through the PET membrane with different applied voltages is presented in Figure 5. The promotive effect of potential on flux can be seen in Figure 5 , that as the potential was increased, the flux of $\mathrm{CV}^{+}$gave a direct correlation as expected. This correlation can be explained by the contributing forces to the transport (i.e., electro-osmosis, electrophoresis) of the analyte. When there is no electric field applied, the transport is only due to diffusion from feed cell to the permeate cell because of the concentration gradient; however, as a certain potential is applied, electrophoretic and electro-osmotic forces also contribute to the transport, driving the positively charged analyte to thecounter electrode (i.e., cathode side). 


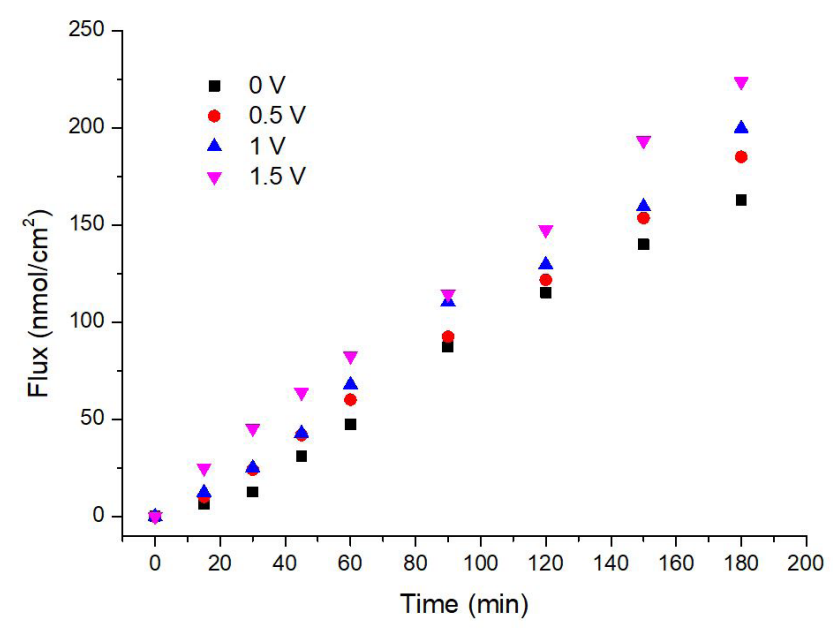

Figure 5. $\mathrm{CV}^{+}$flux under various applied potentials.

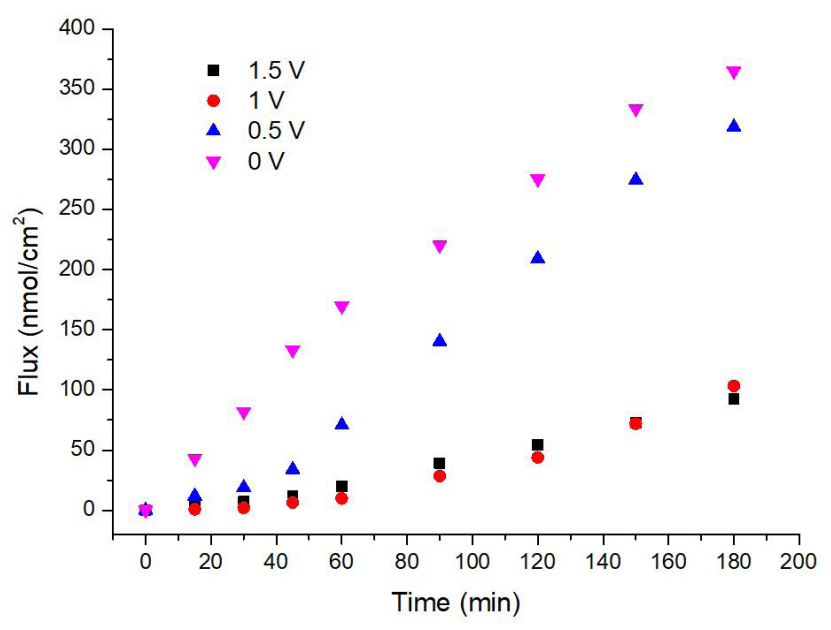

Figure 6. MO flux under various potentials.

In order to compare the nanopore selectivity towards oppositely charged analytes, MO was transported through the same membrane under various potentials. The effect of potential on MO flux was the opposite of $\mathrm{CV}+$ and is shown in Figure 6 . The negatively charged analyte is driven to the anode (the feed cell) electrophoretically under applied potential which decreases the overall molecular flux of MO.

The plots between molecular flux and time were all linear with $\mathrm{R}^{2}$ values over 0.990 and 0.938 for $\mathrm{CV}^{+}$and $\mathrm{MO}^{-}$, respectively. Transport rates ( $\mathrm{nmol}$. $\mathrm{cm}^{-2} \mathrm{~min}^{-1}$ ) were calculated from the slope of these linear plots. In order to inspect the selectivity of the membrane towards the positively charged analyte $\mathrm{CV}^{+}$, selectivity coefficients which are defined as the ratio of transport rates of the analytes were calculated using Equation 2. The obtained values are presented in Table 1.
The results indicated that with the increasing potential, the membrane became selective towards the positively charged analyte $\mathrm{CV}^{+}$. When no potential was applied, MO was transported with a higher rate than that of $\mathrm{CV}^{+}$which contradicts with the argument of PET being selective towards

$\alpha=\frac{\operatorname{Rate}\left(C V^{+}\right)}{\operatorname{Rate}\left(M O^{-}\right)}$

positively charged analytes. But in our case, the analytes differ in molecular volume and structure so that the net charge of the molecule is not the only contributing factor to the permeation rate. MO which is an azo dye has a molecular volume of $257 \AA^{3}$ whereas the triarylmethane dye, $\mathrm{CV}^{+}$has a molecular volume of $378 \AA^{3}$. 
Table 1. Selectivity coefficients with respect to applied potential.

\begin{tabular}{cccc}
\hline \multirow{2}{*}{ Potential (V) } & \multicolumn{2}{l}{ Rate $\left(\mathrm{nmol.c \textrm {cm } ^ { - 2 } \cdot \mathrm { min } ^ { - 1 } )}\right.$} & \multirow{2}{*}{ Selectivity $(\alpha)$} \\
\cline { 2 - 3 } & $\mathrm{MO}$ & $\mathrm{CV}^{+}$ & 0.49 \\
\hline 0 & 2.03 & 0.99 & 0.55 \\
\hline 0.5 & 1.92 & 1.05 & 1.97 \\
\hline 1 & 0.57 & 1.12 & 2.30 \\
\hline 1.5 & 0.53 & 1.22 & \\
\hline
\end{tabular}
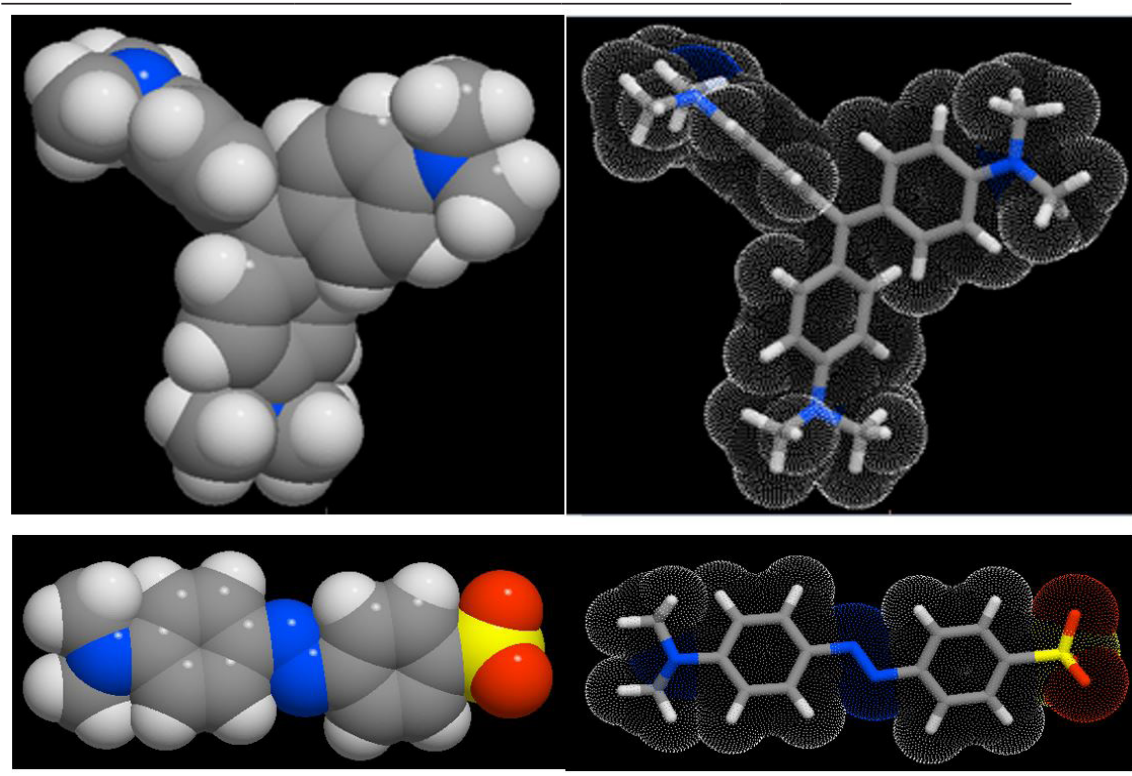

Figure 7. Molecular structures of $\mathrm{CV}^{+}$and $\mathrm{MO}^{-}$(Produced using Molinspiration Cheminformatics Software [39].

This difference in molecular volume, and the linear structure of $\mathrm{MO}^{-}$(shown in Figure 7) enhances its transport rate. Therefore without any applied potential, its transport rate is higher than $\mathrm{CV}^{+}$despite having a negative charge. But as the potential is increased, electrokinetic phenomena (i.e. electrophoretic and electro-osmotic forces) have a significant impact on transport selectivity towards positively charged analyte, $\mathrm{CV}^{+}$.

\section{Effect of Temperature on Analyte Transport Rate}

Another parameter of interest on transport rate was temperature. The transport of $\mathrm{CV}^{+}$through $25 \pm 1 \mathrm{~nm}$ pore membrane was carried on under 1.5 $\checkmark$ potential and four different temperature values. According to the obtained results, transport rate increased from 1.22 to $7.23 \mathrm{nmol} . \mathrm{cm}^{-2} \cdot \mathrm{min}^{-1}$ as a function of temperature which was raised from $298 \mathrm{~K}$ to $328 \mathrm{~K}$, respectively (Figure 8 ). This behavior indicated that the transport of the $\mathrm{CV}^{+}$ has an endothermic nature and favored higher temperatures (due to the positive dependence of diffusion coefficient to temperature). Arrhenius equation can be used to explain the temperature dependence of diffusion coefficient (Equation 3); where $D$ is the diffusion coefficient, $D_{0}$ is the diffusion coefficient at infinite temperature, $E_{a}$ is the activation energy, $T$ is the absolute temperature and $\mathrm{k}$ is the Boltzmann constant.

\section{Effect of Pore Geometry on Analyte Transport Rate}

In order to investigate the effect pore geometry on the transport rate of the analyte, multiporous PET membranes with conical geometries were fabricated andsubsequently used for the transport of $\mathrm{CV}^{+}$. The prepared nanopores

$D=D_{0} e^{-\frac{E_{a}}{k T}}$

had tip openings of $25 \mathrm{~nm}$ for comparison with cylindrical ones. This was achieved through a second etching step developed by Wharton et. al. [40]. Shortly, after the first step of etching, a more dilute etching solution ( $2 \mathrm{M} \mathrm{NaOH}$ ) was introduced in both half cells and under a transmembrane potential of $1 \mathrm{~V}$. This second step 


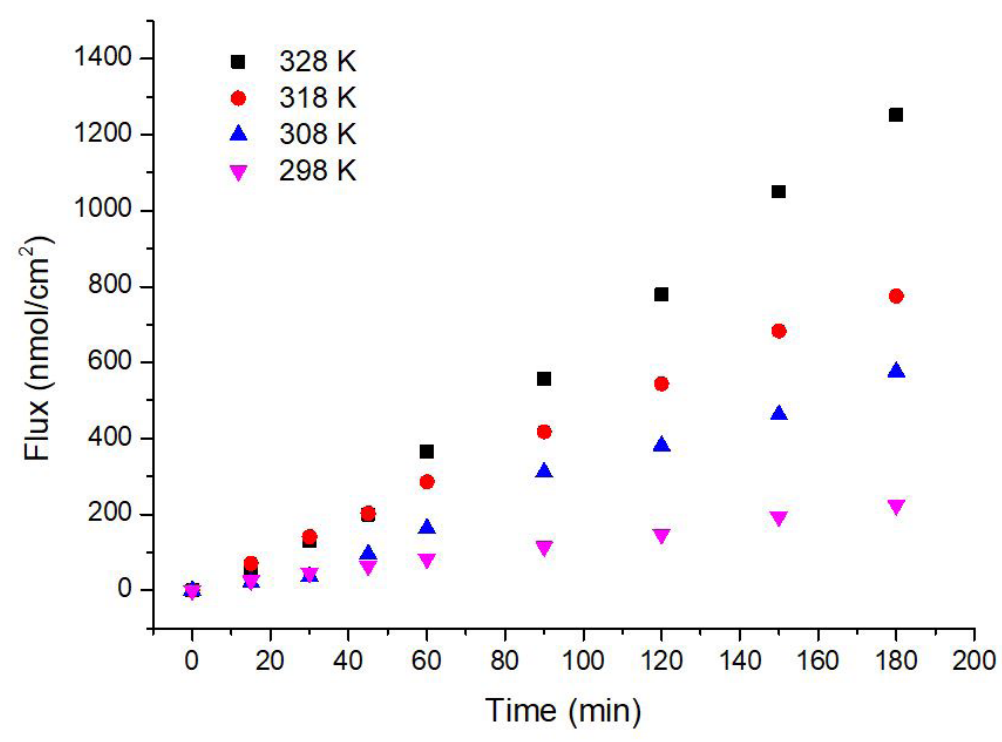

Figure 8. Temperature dependence of $\mathrm{CV}^{+}$flux.

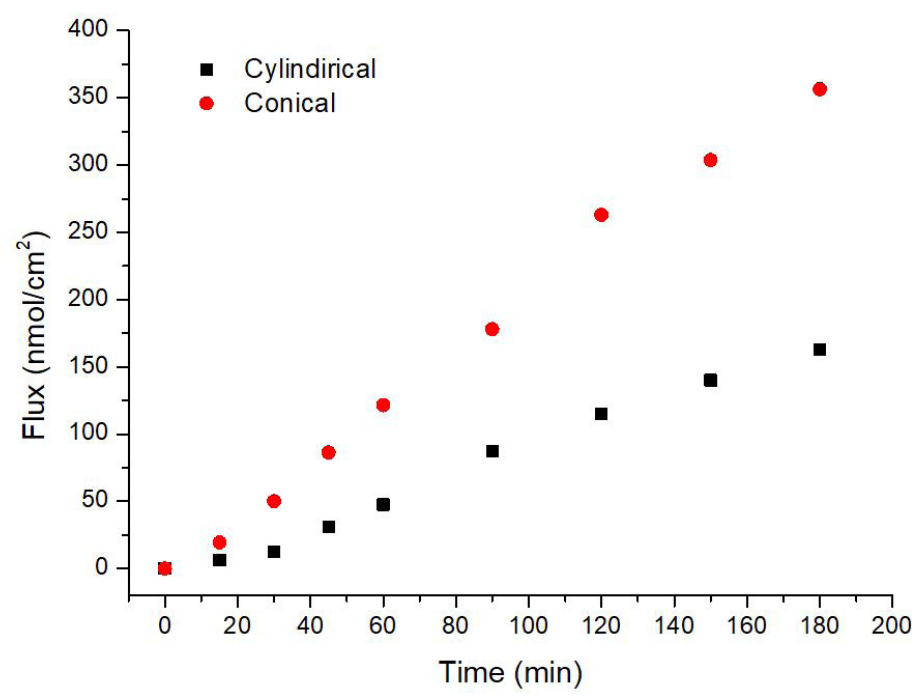

Figure 9. $\mathrm{CV}^{+}$flux through pores with different geometries.

of etching was stopped when the pore reached the desired size by monitoring the current values and once again the etching solution was replaced with the stopping solution content to terminate further widening of the pore. Thereafter, the half cells were rinsed with water and the membrane was then used for the experiments.

Analyte was added to the tip side of the membrane and the transport of $\mathrm{CV}^{+}$through the membrane was performed. The dependence of $\mathrm{CV}^{+}$ flux to nanopore geometry is shown in Figure 9. It is obvious that the transport rate significantly increased when the nanopores have conical geometry. The trapping zone, which is formed near the nanopores' tip entrance, was shown to have a positive effect on the transport of charged analyte doubling its molecular flux. The effects of nanopore geometry on the sensing phenomena have been widely researched especially for single nanopores and it was shown that the ionic current is directly affected by the pore's resistance which is related to the pore's geometry [41]. Furthermore, the promotive effect of conical geometry was previously reported for multipore asymmetrical nanopores for the transport of charged analytes as well [42]. Further investigations were performed to analyze the effect of geometry on 


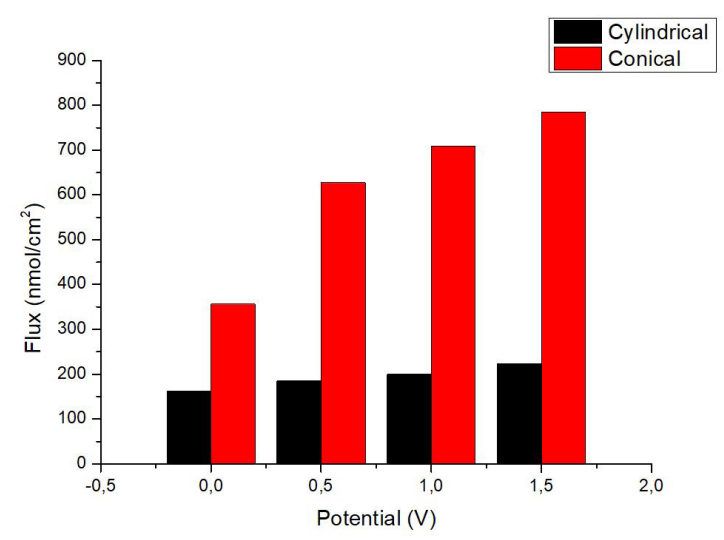

Figure 10. $\mathrm{CV}^{+}$flux through pores with different geometries at various potentials.

the molecular flux at varying potentials (Figure 10). Once more it was shown that the potential has a promoting effect on $\mathrm{CV}^{+}$transport because applying a potential entails electrophoretic forces that enhance the transport of positively charged analyte. It was also found that the increase in the flux was more significant for conically shaped pores than that of cylindrical ones.

\section{Conclusion}

In conclusion, we have demonstrated the effect of potential, pore geometry and temperature (etc.) on the transport phenomenon by the transport rate of charged dye molecules across a track-etched polymeric membrane. We have shown here that the nanoporous membranes can be used as molecular sieves, can show transport selectivity, and can be used both for anions and cations. Applying potential across the membrane has promoted the transport of $\mathrm{CV}^{+}$but decreased the transport of $\mathrm{MO}$, thus increased the membrane selectivity towards positively charged analyte. The studies on the geometry of nanopore showed that the transport of $\mathrm{CV}^{+}$was faster using a conical nanopore. In addition, high temperature was also found to enhance the flux of $\mathrm{CV}^{+}$. The nanopore diameter and its geometry can be arranged, so, these membranes are applicable for model studies and for fundamental investigation of how the transport phenomena occur. We are pursuing possible applications of track-etched polymer membranes in chemical and bio-separations and sensors. For such applications, flux or throughput across the membrane is an important issue and these membranes perhaps hold promise for the development of highly selective membranes for chemical separations and sensors.

\section{Acknowledgements}

This work is performed at the Laboratory of Natural Sciences, Istanbul Medeniyet University.

\section{References}

1. H. Hatori, H. Takagi, Y. Yamada, Gas separation properties of molecular sieving carbon membranes with nanopore channels, Carbon, 42 (2004) 1169-1173.

2. S.G. Lemay, Nanopore-based biosensors: the interface between ionics and electronics, ACS nano, 3 (2009) 775-779.

3. A.S. Prabhu, T.Z.N. Jubery, K.J. Freedman, R. Mulero, P. Dutta, M.J. Kim, Chemically modified solid state nanopores for high throughput nanoparticle separation, J. Phys. Condens. Matter, 22 (2010) 454107.

4. S.B. Lee, D.T. Mitchell, L. Trofin, T.K. Nevanen, H. Söderlund, C.R. Martin, Antibody-based bio-nanotube membranes for enantiomeric drug separations, Science, 296 (2002) 2198-2200.

5. J. Kasianowicz, E. Brandin, D. Branton, D.W. Deamer, Characterization of individual polynucleotide molecules using a membrane channel, Proc. Natl. Acad. Sci. U.S.A., 93 (1996) 13770-13773.

6. S.M. Bezrukov, M. Winterhalter, Examining noise sources at the single-molecule level: $1 / \mathrm{f}$ noise of an open maltoporin channel, PRL, 85 (2000) 202.

7. C. Dekker, Solid-state nanopores, Nat. Nanotechnol., 2 (2007) 209-215.

8. K.K. Hu, Y.X. Wang, H.J. Cai, M.V. Mirkin, Y. Gao, G. Friedman, Y. Gogotsi, Open Carbon Nanopipettes as Resistive-Pulse Sensors, Rectification Sensors, and Electrochemical Nanoprobes, Anal. Chem., 86 (2014) 8897-8901. 
9. H.M. Kim, M.H. Lee, K.B. Kim, Theoretical and experimental study of nanopore drilling by a focused electron beam in transmission electron microscopy, Nanotechnology, 22 (2011) 275303.

10. A.G. Ahmadi, S. Nair, Geometry of nanopore devices fabricated by electron beam lithography: Simulations and experimental comparisons, Microelectron. Eng. 112 (2013) 149-156.

11. N.L. Kazanskiy, S.P. Murzin, Y.L. Osetrov, V.I. Tregub, Synthesis of nanoporous structures in metallic materials under laser action, Opt. Lasers Eng., 49 (2011) 1264-1267.

12. N. Patterson, D. Adams, V. Hodges, M. Vasile, J. Michael, P. Kotula, Controlled fabrication of nanopores using a direct focused ion beam approach with back face particle detection, Nanotechnology, 19 (2008) 235304.

13. J. He, L. Lin, P. Zhang, S. Lindsay, Identification of DNA basepairing via tunnel-current decay, Nano Lett. 7 (2007) 3854-3858.

14. P.Y. Apel, Y.E. Korchev, Z. Siwy, R. Spohr, M. Yoshida, Diode-like single-ion track membrane prepared by electro-stopping, Nucl. Instrum. Methods Phys. Res. B., 184 (2001) 337-346.

15. P.Y. Apel, I.V. Blonskaya, O.L. Orelovitch, B.A. Sartowska, R. Spohr, Asymmetric ion track nanopores for sensor technology. Reconstruction of pore profile from conductometric measurements, Nanotechnology, 23 (2012) 225503

16. V. Chavan, C. Agarwal, A.K. Pandey, J.P. Nair, P. Surendran, P.C. Kalsi, A. Goswami, Controlled development of pores in polyethylene terepthalate sheet by room temperature chemical etching method, J. Memb. Sci., 471 (2014) 185-191.

17. A. Kocer, L. Tauk, P. Dejardin, Nanopore sensors: From hybrid to abiotic systems, Biosens. Bioelectron., 38 (2012) 1-10.

18. A. Mara, Z. Siwy, C. Trautmann, J. Wan, F. Kamme, An Asymmetric Polymer Nanopore for Single Molecule Detection, Nano Lett., 4 (2004) 497-501.

19. C.A. Merchant, K. Healy, M. Wanunu, V. Ray, N. Peterman, J. Bartel, M.D. Fischbein, K. Venta, Z. Luo, A.C. Johnson, DNA translocation through graphene nanopores, Nano Lett., 10 (2010) 2915-2921.

20. D. Cohen-Tanugi, J.C. Grossman, Water desalination across nanoporous graphene, Nano Lett., 12 (2012) 3602-3608.

21. H.Bayley, Are we there yet ? Comment on "Nanopores: A journey towards DNA sequencing" by Meni Wanunu, Phys. Life Rev., 9 (2012) 161-163.

22. T.C. Kuo, L.A. Sloan, J.V. Sweedler, P.W. Bohn, Manipulating molecular transport through nanoporous membranes by control of electrokinetic flow: effect of surface charge density and Debye length, Langmuir, 17 (2001) 6298-6303.

23. S.P. Adiga, C. Jin, L.A. Curtiss, N.A. Monteiro Riviere, R.J. Narayan, Nanoporous membranes for medical and biological applications, Wiley Interdiscip. Rev. Nanomed. Nanobiotechnol., 1 (2009) 568-581.

24. T.A. Desai, S. Sharma, R.J. Walczak, A. Boiarski, M. Cohen, J. Shapiro, T. West, K. Melnik, C. Cosentino, P.M. Sinha, Nanoporous implants for controlled drug delivery, BioMEMS and Biomedical Nanotechnology Volume III, Springer, Berlin, Germany, 2006.
25. S. Kipke, G. Schmid, Nanoporous alumina membranes as diffusion controlling systems, Adv. Funct. Mater., 14 (2004) 1184-1188.

26. L. Velleman, G. Triani, P.J. Evans, J.G. Shapter, D. Losic, Structural and chemical modification of porous alumina membranes, Microporous Mesoporous Mater., 126 (2009) 87-94.

27. C.J. Lo, T. Aref, A. Bezryadin, Fabrication of symmetric sub-5 nm nanopores using focused ion and electron beams, Nanotechnology, 17 (2006) 3264.

28. G.F. Schneider, S.W. Kowalczyk, V.E. Calado, G. Pandraud, H.W. Zandbergen, L.M. Vandersypen, C. Dekker, DNA translocation through graphene nanopores, Nano Lett., 10 (2010) 3163-3167.

29. S.B. Lee, C.R. Martin, pH-Switchable, ionpermselective gold nanotubule membrane based on chemisorbed cysteine, Anal. Chem., 73 (2001) 768775.

30. K.B. Jirage, J.C. Hulteen, C.R. Martin, Nanotubulebased molecular-filtration membranes, Science, 278 (1997) 655-658

31. S.B. Lee, C.R. Martin, Electromodulated molecular transport in gold-nanotube membranes, J. Am. Chem. Soc., 124 (2002) 11850-11851.

32. K.B. Jirage, J.C. Hulteen, C.R. Martin, Effect of thiol chemisorption on the transport properties of gold nanotubule membranes, Anal. Chem., 71 (1999) 49134918.

33. S. Yu, S.B. Lee, C.R. Martin, Electrophoretic protein transport in gold nanotube membranes, Anal. Chem., 75 (2003) 1239-1244.

34. E.N. Savariar, K. Krishnamoorthy, S. Thayumanavan, Molecular discrimination inside polymer nanotubules, Nat. Nanotechnol., 3 (2008) 112-117.

35. M. Ali, B. Yameen, R. Neumann, W. Ensinger, W. Knoll, O. Azzaroni, Biosensing and supramolecular bioconjugation in single conical polymer nanochannels, facile incorporation of biorecognition elements into nanoconfined geometries, J. Am. Chem. Soc., 130 (2008) 16351-16357.

36. Q.H. Nguyen, M. Ali, V. Bayer, R. Neumann, W. Ensinger, Charge-selective transport of organic and protein analytes through synthetic nanochannels, Nanotechnology, 21 (2010) 365701.

37. K. Kececi, N. San, D. Kaya, Nanopore detection of double stranded DNA using a track-etched polycarbonate membrane, Talanta, 144 (2015) 268274.

38. Z. Siwy, P. Apel, D. Baur, D.D. Dobrev, Y.E. Korchev, R. Neumann, R. Spohr, C. Trautmann, K.O. Voss, Preparation of synthetic nanopores with transport properties analogous to biological channels, Surf. Sci., 532 (2003) 1061-1066.

39. Molinspiration Cheminformatics Software. 2001, Molinspiration: Nova Ulica, SK-900 26 Slovensky Grob, Slovak Republic.

40. J.E. Wharton, P. Jin, L.T. Sexton, L.P. Horne, S.A. Sherrill, W.K. Mino, C.R. Martin, A method for reproducibly preparing synthetic nanopores for resistive-pulse biosensors, Small, 3 (2007) 1424-1430. 
41. D. Kaya, A. Dinler, N. San, K. Kececi, Effect of Pore Geometry on Resistive-Pulse Sensing of DNA Using Track-Etched PET Nanopore Membrane, Electrochim. Acta, 202 (2016) 157-165.
42. Q.H. Nguyen, M. Ali, S. Nasir, W. Ensinger, Transport properties of track-etched membranes having variable effective pore-lengths, Nanotechnology, 26 (2015) 485502. 
